Document downloaded from:

http://hdl.handle.net/10251/37504

This paper must be cited as:

Martínez Gil, P.; Laguarda Miró, N.; Soto Camino, J.; Masot Peris, R. (2013). Glyphosate detection with ammonium nitrate and humic acids as potential interfering substances by pulsed voltammetry technique. Talanta. (115):702-705. doi:10.1016/j.talanta.2013.06.030.

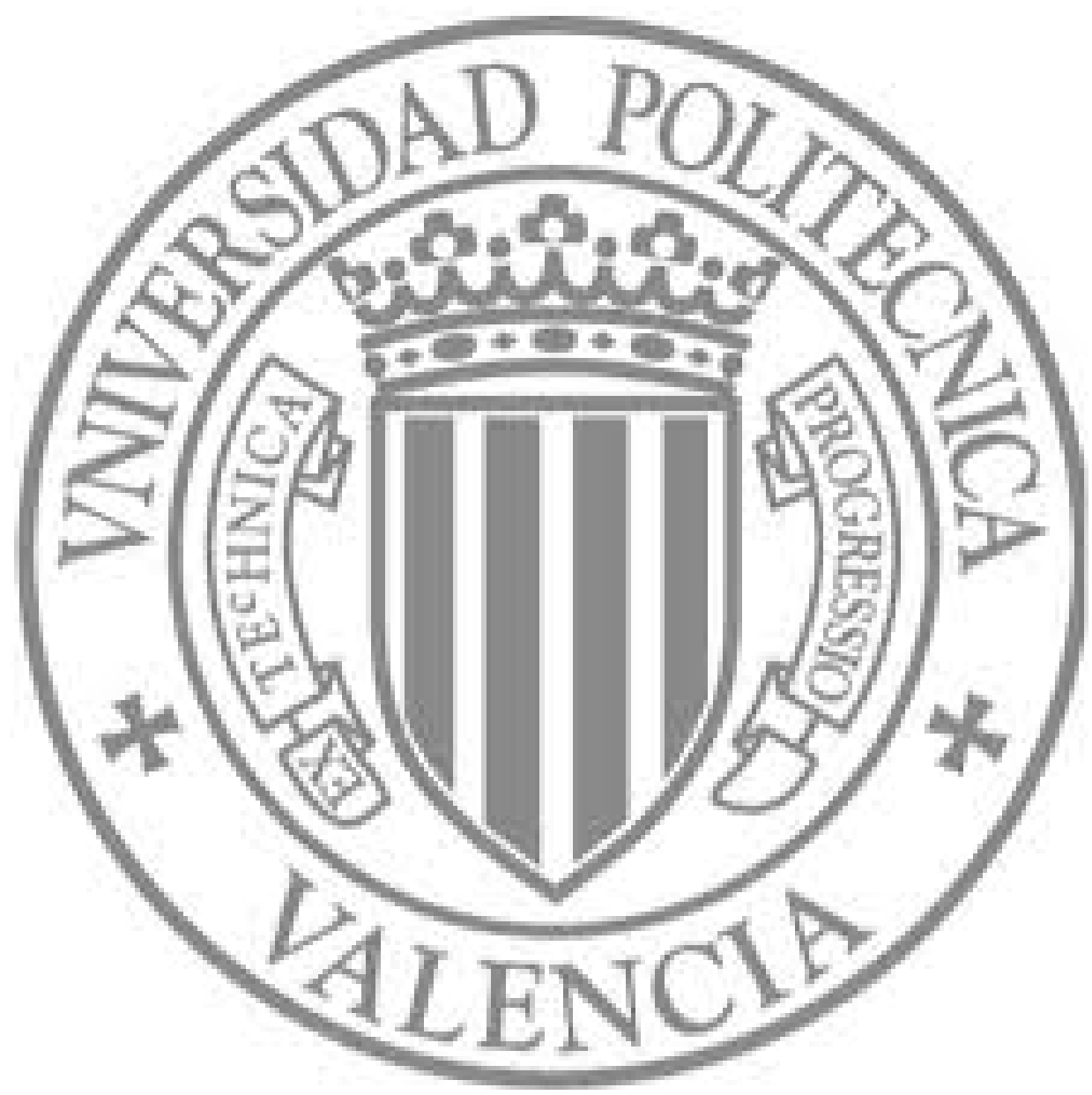

The final publication is available at

http://dx.doi.org/10.1016/j.talanta.2013.06.030

Copyright Elsevier 


\title{
Glyphosate detection with ammonium nitrate and humic acids as potential interfering substances by pulsed voltammetry technique.
}

\author{
Pablo Martínez Gil ${ }^{1}$, Nicolas Laguarda-Miro, ${ }^{1,2^{\star}}$, Juan Soto Camino ${ }^{1,3}$, Rafael Masot \\ Peris $^{1,4}$ \\ ${ }^{1}$ Instituto Reconocimiento Molecular y Desarrollo Tecnológico. Universitat Politècnica de València, \\ Cami de Vera s/n, 46022, Valencia, Spain. \\ ${ }^{2}$ Departamento de Ingeniería Química y Nuclear. Universitat Politècnica de València, Cami de Vera s/n, \\ 46022, Valencia, Spain. \\ ${ }^{3}$ Departamento de Química. Universitat Politècnica de València, Cami de Vera s/n, 46022, Valencia, \\ Spain. \\ ${ }^{4}$ Departamento de Ingeniería Electrónica. Universitat Politècnica de València, Cami de Vera s/n, \\ 46022, Valencia, Spain.
}

*Corresponding Author: nilami@iqn.upv.es

\begin{abstract}
Pulsed voltammetry has been used to detect and quantify glyphosate on buffered water in presence of ammonium nitrate and humic substances. Glyphosate is the most widely used herbicide active ingredient in the world. It is a non-selective broad spectrum herbicide but some of its health and environmental effects are still being discussed. Nowadays, glyphosate pollution in water is being monitored but quantification techniques are slow and expensive. Glyphosate wastes are often detected in countryside water bodies where organic substances and fertilizers (commonly based on ammonium nitrate) may also be present. glyphosate also forms complexes with humic acids so these compounds have also been taken into consideration. The objective of this research is to study the interference of these common pollutants in glyphosate measurements by pulsed voltammetry. The statistical treatment of the voltammetric data obtained lets us discriminate glyphosate from the other studied compounds and a mathematical model has been built to quantify glyphosate concentrations in a buffer despite the presence of humic substances and ammonium nitrate. In this model, the coefficient of determination $\left(R^{2}\right)$ is 0.977 and the RMSEP value is $2.96 \times 10^{-5}$ so the model is considered statistically valid.
\end{abstract}

Keywords: voltammetry, glyphosate, ammonium nitrate, humic substance, mathematical model. 


\section{Introduction}

Glyphosate is the most widely used herbicide active ingredient in the world [1]. This is due mainly to the widespread use of glyphoresistant seeds [2], which inhibits the growth of competitive weeds in combination with glyphosate [3][4] allowing crops to be very productive and efficient at low cost [5][6]. Glyphoresistant seeds are genetically modified organisms, mainly soya, corn, canola, wheat, sugar beet, and cotton [7].

Glyphosate is a non-selective wide spectrum herbicide. It works by inhibiting the enzyme EPSPS from plants, which is essential for the development of certain amino acids. In the environment, it has a half-life between 7 and 174 days [8][9] and metabolizes into AMPA, methylamine, ammonia, and carbon dioxide[10]. Extensive and recurrent uses, as well as an inappropriate product application, cause its presence in unwanted areas and glyphosate can be found in soil [11], water [12][13], crops [14], plants [2], animals [15], and human inhabited areas [16], with a significant toxicological and environmental potential damage [17].

Despite the lack of control and legislation of this herbicide in many countries [18], the USEPA is the worldwide legal reference in terms of limit concentrations for glyphosate in water bodies [19][20][21], setting a maximum concentration of $0.7 \mathrm{mg} / \mathrm{l}$. In addition, the Health Canada Drinking Water Guidelines set $0.28 \mathrm{mg} / \mathrm{l}$ as its Maximum Acceptable Concentration in drinking waters [22][23]. There are directives and regulations based on these organizations guidelines in most of the developed countries, such as the Water Framework Directive 2006/60 CE in European Union [24].

Nowadays, glyphosate is mainly detected and quantified by High Performance Liquid Chromatography combined with mass spectrometry (HPLC-MS) [17][25] but there are other applied techniques such as fluorescence, colorimetry [26], caplillary electrophoresis [27], and electrochemilumnescence [28]. These techniques are slow and expensive and must be developed in a laboratory, so pulsed voltammetry may become a feasible alternative.

In fact, voltammetric techniques are showing good results in various research areas like pollutants detection in air [13], water [10], and food [29]. In addition, they are starting to be considered as promissory alternatives to the traditional analytical methods in several fields by developing an appropriate selection of metals and coatings. Some examples of this success can be seen in published papers such as the one presented by Aquino [30], or using an appropriate combination of diverse metals as silver and platinum [31], copper [32], enzymes [33], and double-layer hydroxides [34] as working electrodes and coatings.

The main goal of this paper is to build and validate a mathematical model to quantify glyphosate in a buffer solution despite the presence of different concentrations of some common pollutants in natural water bodies that can be possible interfering substances. Several assays have been carried out with different concentrations of glyphosate, ammonium nitrate and liquid humus dissolved in $0.1 \mathrm{M}$ sodium dihydrogen phosphate. 


\section{Materials and methods}

\section{$\underline{\text { Chemicals }}$}

Voltammetry measurements have been done to different dissolutions combining five glyphosate concentrations (96\%, Molekula) ranging from 5.10-5 $\mathrm{M}$ to $5 \cdot 10-4 \mathrm{M}$, three different concentrations of ammonium nitrate (ACS reagent, 98\%, Sigma-Aldrich) ranging from $10 \mathrm{ppm}$ to $100 \mathrm{ppm}$, and other three ones of a commercial liquid humus $(\mathrm{C} / \mathrm{N}=12.5, \mathrm{pH}=4.5$, density $=1,24 \mathrm{~kg} / \mathrm{l}, 2.2 \%$ nitrogen. Commercial product from MasoGarden) from $5 \mathrm{ppm}$ to $50 \mathrm{ppm}$, all of them dissolved on $0.1 \mathrm{M}$ sodium dihydrogen phosphate (ACS reagent, Sharlau).

\section{Electrochemical measurement}

All measurements have been carried out with an electronic device designed and developed by the Institute of Molecular Recognition and Technological Development (IDM) called FraPlusMini [35][36][37] that is capable to run tests of pulsed voltammetry, cyclic voltammetry and impedance spectroscopy. This electronic device and measurement system has been described in detail in previous papers working with glyphosate [18][29] and has been successfully used in food [38][39][40], water analyses [41] and the determination of environmental parameters [42].

As in the previous works with glyphosate [18][29], pulsed voltammetry technique was used to apply an electric voltage to the utilized electrodes (working electrodes) when submerged in glyphosate dissolutions. Then the electric current that circulates through each electrode could be measured. This is because the flow of the current through the dissolution is a function of the applied voltage and the chemical concentration in the dissolution.

\section{Electrochemical sensors (electrodes)}

In order to carry out the analyses, two different arrays of metal sensors have been developed. Each array has been confined in a stainless steel tube as shown in figure 1. The first one containing four different noble metals (Ir, Rh, Pt, Au) and the second one containing other four non-noble metals $(\mathrm{Ag}, \mathrm{Cu}, \mathrm{Co}, \mathrm{Ni})$. Every working electrode has a contact diameter of $1 \mathrm{~mm}$. Not only how the metal sensors are fixed inside of the steel body is important, but also the connection between the sensors and the cables connected to the measurement system. In this sense, each array of sensors has been connected to the measurement system using cables soldered to a crimp-on terminal. Next, each steel cylinder has been filled up with epoxy resin in order to fix the metal sensors, separate them and guarantee the contact surface of $1 \mathrm{~mm}$ in diameter for all the sensors. In the end, in order to guarantee a full contact of all the sensors, the overflowing resin of the metal sensor was sanded (Figure 1). 


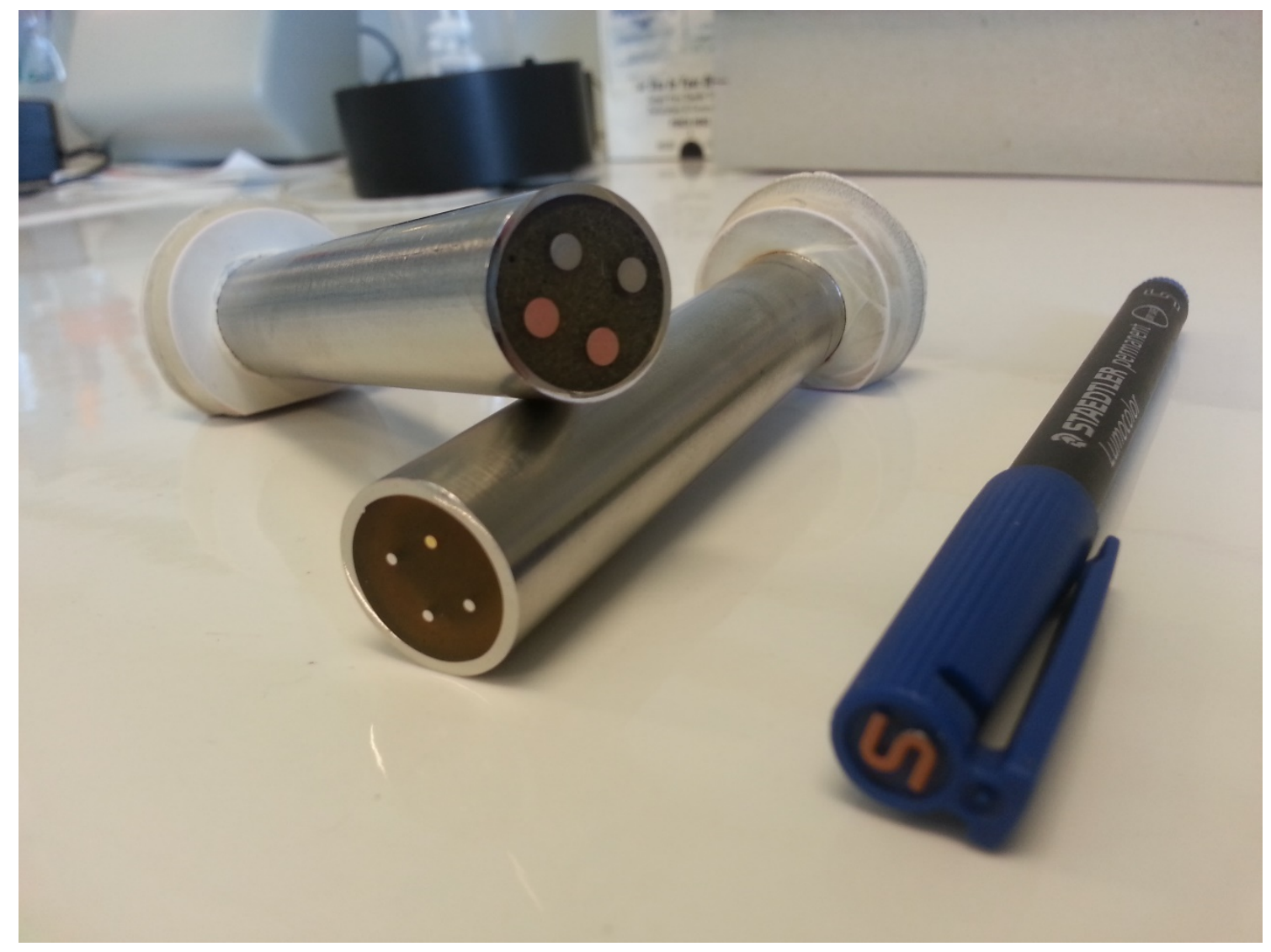

Figure 1.- Example of the designed electrode arrays.

The selection of the metal sensors used to develop the arrays has been made according to our previous experience [18][42] and papers published before [43][44]. In addition, a calomel electrode has been used (Radiometer Analytical, XR 100) as reference electrode.

\section{Laboratory analyses}

Attending to the experience acquired in previous works [18][42][43] and the preliminary tests with glyphosate in buffer dissolution, a pulse train (figure 2) has been designed and used in order to carry out the voltammetric measurements. 


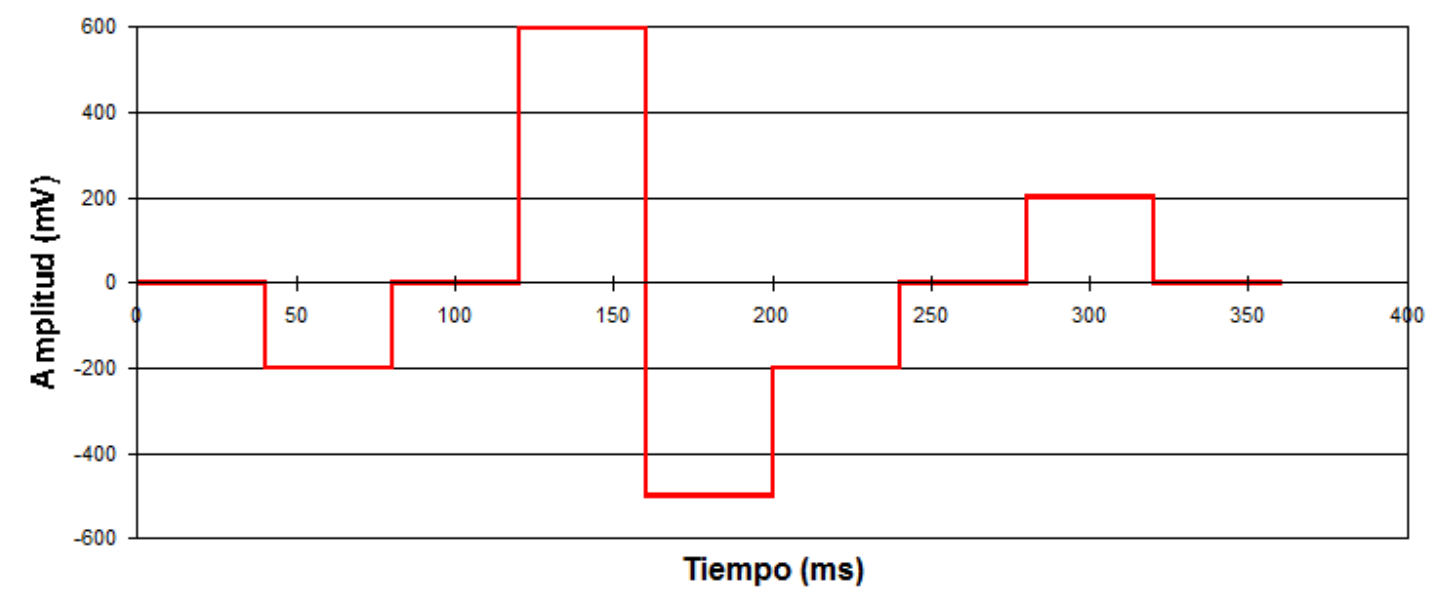

Figure 2.- Pulse train used to carry out the experiences with pulsed voltammetry.

Electrochemical analyses have been done by using the FraPlusMini device to samples with five different concentrations of glyphosate, three different ones of ammonium nitrate, and three different ones of liquid humus dissolved on a buffer solution of $0.1 \mathrm{M}$ sodium dihydrogen phosphate adjusted to a $\mathrm{pH}$ of 6.7 with a few drops of $\mathrm{NaOH}$. As a result of these combinations a global amount of 31 samples (thirty plus the buffer sample) per series have been selected attending to an appropriate distribution of glyphosate, ammonium nitrate and humus concentrations (table 1)

Table 1.- Chemical composition of the selected samples to build the mathematical model.

\begin{tabular}{|c|c|c|c|c|c|c|c|c|c|c|c|}
\hline Sample & Glypho & $\mathrm{NH}_{4} \mathrm{NO}_{3}$ & Humus & Sample & Glypho & $\mathrm{NH}_{4} \mathrm{NO}_{3}$ & Humus & Sample & Glypho & $\mathrm{NH}_{4} \mathrm{NO}_{3}$ & Humus \\
\hline 1 & $5 \mathrm{E}-04 \mathrm{M}$ & $100 \mathrm{ppm}$ & 50ppm & 11 & $5 \mathrm{E}-04 \mathrm{M}$ & $100 \mathrm{ppm}$ & $5 p p m$ & 21 & $5 \mathrm{E}-04 \mathrm{M}$ & $100 \mathrm{ppm}$ & 50ppm \\
\hline 2 & $\begin{array}{l}3.5 \mathrm{E}- \\
04 \mathrm{M}\end{array}$ & $100 \mathrm{ppm}$ & 50ppm & 12 & $3.5 \mathrm{E}-04 \mathrm{M}$ & 100ppm & $5 p p m$ & 22 & $5 \mathrm{E}-04 \mathrm{M}$ & 100ppm & 50ppm \\
\hline 3 & $2 \mathrm{E}-04 \mathrm{M}$ & 100ppm & 50ppm & 13 & $2 \mathrm{E}-04 \mathrm{M}$ & 100ppm & $5 p p m$ & 23 & $5 E-04 M$ & 100ppm & 50ppm \\
\hline 5 & $5 \mathrm{E}-05 \mathrm{M}$ & 100ppm & 50ppm & 15 & $5 \mathrm{E}-05 \mathrm{M}$ & 100ppm & $5 p p m$ & 25 & $5 \mathrm{E}-04 \mathrm{M}$ & 100ppm & 50ppm \\
\hline 6 & $5 \mathrm{E}-04 \mathrm{M}$ & $10 \mathrm{ppm}$ & $5 p p m$ & 16 & $2 \mathrm{E}-04 \mathrm{M}$ & 10ppm & 50ppm & 26 & $5 \mathrm{E}-04 \mathrm{M}$ & 50ppm & 50ppm \\
\hline 7 & $\begin{array}{l}3.5 \mathrm{E}- \\
04 \mathrm{M}\end{array}$ & $10 \mathrm{ppm}$ & $5 p p m$ & 17 & $2 \mathrm{E}-04 \mathrm{M}$ & $10 p p m$ & 50ppm & 27 & $5 \mathrm{E}-04 \mathrm{M}$ & $10 \mathrm{ppm}$ & $20 p p m$ \\
\hline 10 & $5 \mathrm{E}-05 \mathrm{M}$ & $10 \mathrm{ppm}$ & $5 p p m$ & 20 & $1 \mathrm{E}-04 \mathrm{M}$ & $10 p p m$ & 50ppm & 30 & $5 E-05 M$ & 50ppm & $5 p p m$ \\
\hline
\end{tabular}

During the voltammetric analyses, dissolutions were measured for three times in order to assure repeatability of the samples. In this way, it was possible to perform three series of assays (with three repetitions and five iterations each one) to create sufficient data volume (279 assays) to construct and validate a mathematical model by using SOLO ( ) software (Eigenvector Research Inc.) 


\section{Results and discussion}

\subsection{Voltammetric Analyses}

A data base has been obtained as a result of the three series of assays ( $A, B$ and $C$ ) measured by pulsed voltammetry with the designed pulse train, to the 31 samples of known glyphosate, ammonium nitrate, and liquid humus concentrations in buffer solution. This data base is composed by 999 values of intensity for each one of the 279 assays made. Before starting the statistical treatment, the five iterations of every measure were averaged, as well as the three measures of the same sample, obtaining 93 measures to be statistically treated. This is to simplify the data base and diminish variations among measurements to build the mathematical model. In this data base, three of the 93 measures are buffer measures, which have been subtracted from each one of the measurements of the corresponding series. Therefore, we had to statistically treat 90 measures of the intensity response produced by the dissolved substances.

The voltammetric response to the five glyphosate concentrations in presence of the maximum concentration of ammonium nitrate and humus was in the way shown in figure 3.

\section{Electrodos: $\mathrm{Cu}$}

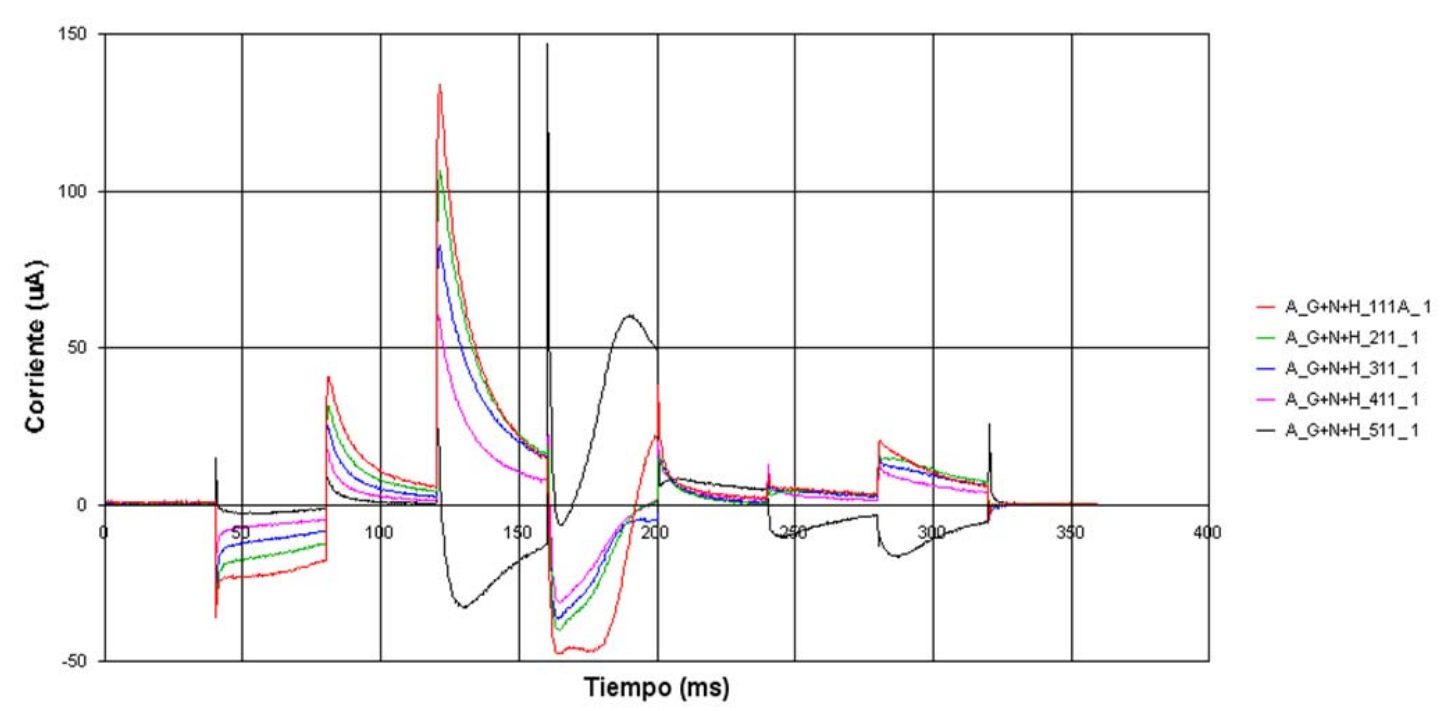

Figure 3.- Electrochemical responses for voltammetric assays to five different Glyphosate concentrations measured with copper electrode.

Figure 3 shows that there is proportionality between the intensity response of some pulses and the known glyphosate concentration, despite the high concentration of ammonium nitrate and humus of each sample. It means that, at least, Copper electrodes are selective to the presence of glyphosate en the buffer but not-selective to the rest of pollutants included in the samples. Attending to this, it was expected to build a mathematical model whose validity and precision could demonstrate that common 
fertilizers and organic substances do not interfere in glyphosate measures by pulsed voltammetry.

\subsection{Mathematical modeling}

Previous statistical treatment was needed to obtain a mathematical model to predict glyphosate concentration in a buffer solution with the mentioned electrochemical method and the applied pulse train. In order to perform this statistical treatment and the mathematical modeling, the software SOLO (c) (Eigenvector Research Inc.) was used. As three series of assays were carried out, an appropriate distribution of the obtained data was made in the following form: Two series of data were used to build the mathematical model and the third one was used to validate it by means of the Venetian Blinds cross-validation method.

The combination of electrodes gave us a wide range of possibilities to build different models, but an accurate study showed that those based on copper and cobalt electrodes were significantly more accurate due to the high intensity response of these two materials.

In order to find the best mathematical model, all the sensors have been studied individually and also combined among them. After building and validating several mathematical models, the best one was the corresponding to the combination of rhodium, copper, and cobalt electrodes. The output of the PLS analysis for these sensors is shown in Figure 4. In this specific case, the coefficient of determination $\left(R^{2}\right)$ is 0.977 and the RMSEP is $2.96 \times 10^{-5}$ so, attending to these values, the proposed model is considered statistically valid. 


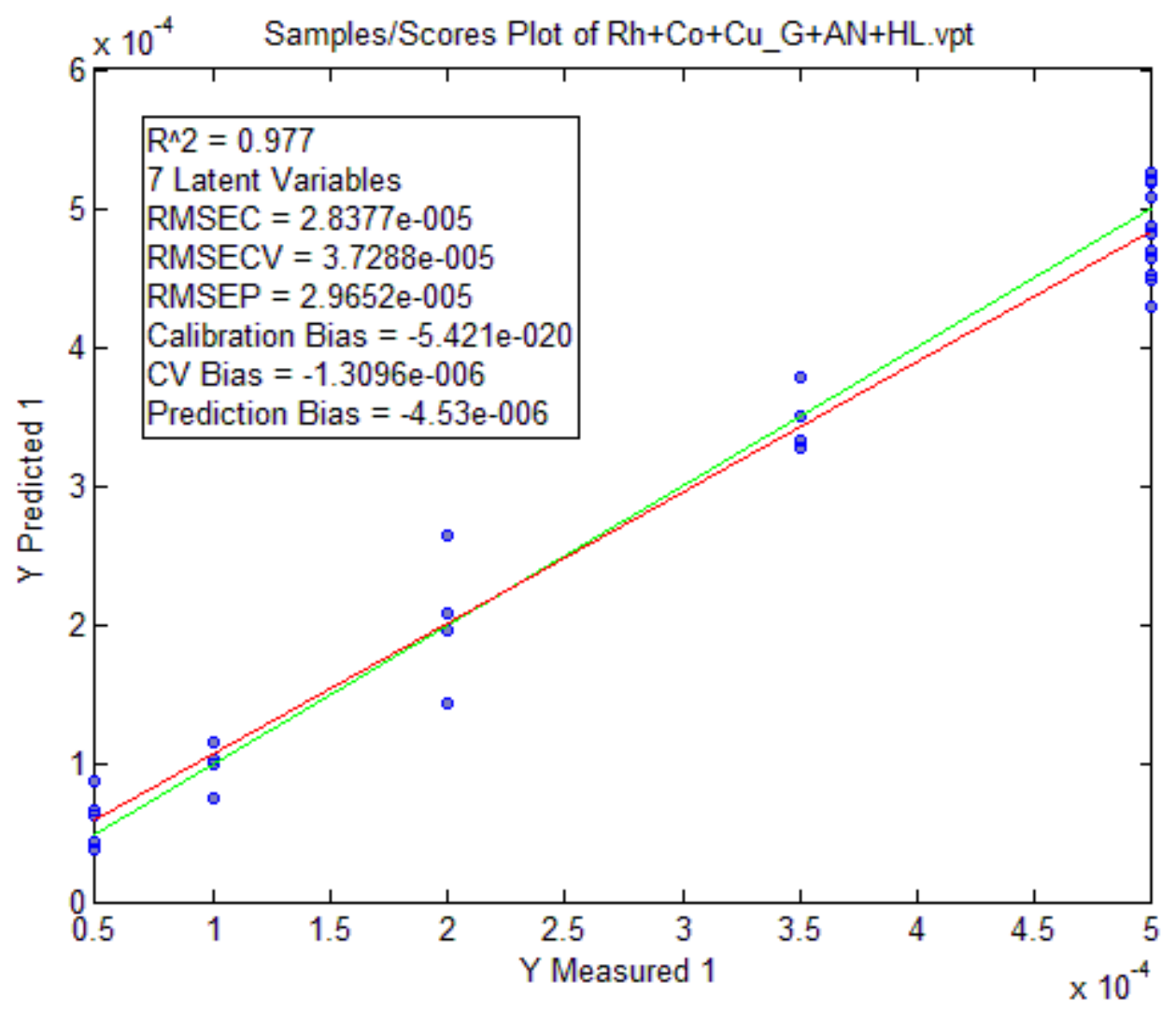

Figure 4.- Measured versus predicted results for Glyphosate concentrations of the model built with Solo $@$ for a combination of the data from rhodium, copper, and cobalt electrodes.

\section{Conclusions}

Glyphosate toxicity and potential carcinogenetic effects are still being discussed, but governments and health and environmental associations, following the US-EPA guidelines, are taking steps to control the presence of glyphosate in food and water. Nowadays, systematic controls for measuring water pollution by glyphosate are being carried out due to its toxicity and potential carcinogenetic effects, but most of the analytical techniques used to quantify it are complex, slow and expensive.

In this paper, we introduce a new method based on voltammetry as an alternative analytical procedure to quantify glyphosate. As we have seen in previous experiences with glyphosate, cobalt and copper electrodes provide a characteristic intensity response that is proportional to the concentration of the herbicide and, in this specific case, rhodium electrode refines the mathematical model. Voltammetric assays using rodhium, copper, and cobalt electrodes have allowed us to build a mathematical model that predicts glyphosate concentration despite the presence of different concentrations of two of the most common pollutants in rural water bodies such as fertilizers (ammonium nitrate) and organic substances (humic substances). In this model, the coefficient of determination $\left(R^{2}\right)$ is 0.977 and the RMSEP value is $2.96 \times 10^{-5}$, so the model is considered statistically valid. Therefore, it is feasible to study the pulsed 
voltammetry technique in combination with this kind of mathematical models as an alternative analytical technique to quantify glyphosate in real water bodies.

\section{Acknowledgements}

Authors acknowledge financial support from the Universitat Politècnica de València and its Centre de Cooperació al Desenvolupament (Programa ADSIDEO-COOPERACIÓ 2010) for the research fellowship. We also thank MICINN (MAT2012-38429-C04-04) and GVA (PPC/2011/019) for their respective research fellowships.

\section{References:}

[1] J.R. Franks. Food Policy 24 (1999) 565-584.

[2] G.S. Johal, D.M. Huber.. Europ. J. Agronomy 31 (2009) 144-152.

[3] W. G. Johnson, V. M. Davis, G. R. Kruger, S. C. Weller. Influence of glyphosateresistant cropping systems on weed species shifts and glyphosate-resistant weed populations. Europ. J. Agronomy 31 (2009) 162-172.

[4] A.D. Baylis. Pest Management Science 56 (2000) 299-308.

[5] W. J. Grichar, E. P. Prostko. Crop Protection 28 (7) (2009) 619-622.

[6] W. G. Johnson, V. M. Davis, G. R. Kruger, S. C. Weller. Europ. J. Agronomy 31 (2009) 162-172

[7] J.A. Scursoni, E. H. Satorre. Crop Protection 29 (2010) 957-962.

[8] C. Accinelli, C. Screpanti, A. Vicari, P. Catizone. Agr Ecosyst Environ 103 (3) (2004) 497-507

[9] Hoja de manejo seguro, ESTELAR 480 SL, Dow Chemical, 1999.

[10] M.A. Bozzo de Brum. Persistencia del glifosato y efecto de sucesivas aplicaciones en el cultivo de soja en agricultura continua en siembra directa sobre parámetros biológicos del suelo. Doctoral Thesis. Univ. de la República, Montevideo (Uruguay), 2010, pp 124.

[11] R.L. Glass. J. Agric. Food Chem. 35 (1997) 497-50

[12] F. Nirascou. Les pesticides dans les eaux. Dossier 5 IFEN (2006) pp36

[13] V.D. Nguyen. P.Valentia, H.W. Nürnberg. Sci. Total Environ 12 (2) (1979), 151-167.

[14] J.W. Sawchuk, R.C.V Van Acker, L.F. Friesen. Weed Technol. 20 (2006) 184-197

[15] K. Sivikova, J. Dianovsky. Int.J. Hyg. Environ.-Health 209 (2006) 15-20

[16] V. Contardo-Jara, E. Klingelmann, C. Wiegand, Environ. Pollut. 157 (2009) 57-63. 
[17] Informe acerca del grado de toxicidad del glifosato. Universidad Nacional del Litoral, Uruguay, 2010, pp 271.

[18] N. Laguarda-Miro, F. Werner Ferreira, E. García-Breijo, J. Ibáñez-Civera, L. GilSánchez, J. Garrigues-Baixauli. Sens. Actuators B: Chem. (2012).

[19] USEPA.glyphosate; Pesticide Tolerances. (http://www.epa.gov/).

[20] USEPA. glyphosate RED Factsheet. (http://www.epa.gov/).

[21] USEPA. 2012 Edition of the Drinking Water Standards and Health Advisories. United States Environmental Protection Agency. (2012).

[22] glyphosate. Guidelines For Canadian Drinking Water Quality - Supporting Documents - glyphosate. Health Canada. (1995). (www.hc-sc.gc.ca).

[23] WHO \& FAO Report. Pesticide Residues in Food 2006. Joint FAO/WHO Meeting on Pesticide Residues. Ed. WHO \& FAO. Rome, 2006, pp 400.

[24] European Parliament. Directive 2000/60/EC of the European Parliament and of the Council of 23 October 2000 establishing a framework for Community action in the field of water policy. Official Journal of the European Communities L 327/1 (2000) pp 72.

[25] M. Corbera Mas. Desenvolupament de metodologia analítica per a la determinació de Glifosat i adjuvants. Doctoral Thesis. Universitat de Girona, 2007, pp 208.

[26] C.F.B. Coutinho, L.F.M. Coutinho, L.H. Mazo, S.L. Nixdorf, C.A.P. Camara. J. Chromatogr. A 1208 (2008), 246 - 249.

[27] H.Y. Chiu, Z.Y. Lin, H. Tu, Ch. Whang. J. Chromatogr. A 1177 (2008) 185 - 198.

[28] J. Jin, F. Takahashi, T. Kaneko, Toshio Nakamura. Electrochim. Acta 55 (2010) $5532-5537$.

[29] M. Alcañiz Fillol. Diseño de un sistema de lengua electrónica basado en técnicas electroquímicas voltamétricas y su aplicación en el ámbito agroalimentario. Doctoral Thesis, Universitat Politècnica de València (2011) pp 295 (http://hdl.handle.net/10251/11303).

[30] S. Aquino Neto, A.R. de Andrade. Electrochim. Acta 54 (2009), 2039 - 2045.

[31] M.A. Méndez, M.F. Suárez, M.T. Cortés, V.M. Sarria. Electrochem. Commun 9 (2007) $2585-2590$.

[32] C.F.B. Coutinho, M.O. Silva, M.L. Calegaro, S.A.S. Mahcado, L.H. Mazo. Solid State Ionics 178 (2007) 161 -164.

[33] E.A. Songa, O.A. Arotiva, J.H.O. Owino, N. Jahed, P.G.L. Baker, E.I. Iwuoha. Bioelectrochemistry 75 (2009) $117-123$.

[34] A, Khenifi, Z. Derriche, C. Forano, V. Prevot, C. Mousty, E. Scavetta, B. Ballarin, L. Guadagnini, D. Tonelli. Anal. Chim. Acta, 654, 2 (2009) 97 - 102.

[35] I. Campos, L. Gil, R. Martínez-Mañez, J. Soto, J.L. Vivancos. Procedia Chemistry 1 (2009) 325-328. 
[36] M.Alcañiz, J.L. Vivancos, R. Masot, J. Ibañez, M. Raga, J. Soto.R. MartínezMáñez. J. Food Eng 111 (2012) 122-128.

[37] I. Campos, M. Alcañiz, R. Masot, J. Soto, R. Martínez-Máñez, J.L. Vivancos, L. Gil. Sens. Actuators B 161 (2012) 556- 563.

[38] L. Gil, J.M. Barat, E. Garcia-Breijo, J. Ibañez, R. Martínez-Máñez, J. Soto, E. Llobet, J. Brezemes, M-C. Aristoy, F. Toldrá. Sens. Actuators B 131 (2008) 362-370.

[39] R.H. Labrador, R. Masot, M. Alcañiz, D. Baigts, R. Martínez-Máñez, E. GarcíaBreijo, L. Gil, J. Soto, J.M. Barat. Food Chem 122 (2010) 864-870.

[40] E. García-Breijo, J.M. Barat, O.L. Torres, R. Grau, J. Ibáñez, M. Alcañiz, R. Masot, R. Fraile, L. Gil. Sens. Actuators A: Phys. 148 (2008) 63-67

[41] E. Garcia-Breijo, J. Atkinson, L. Gil-Sanchez, R. Masot, J. Ibañez, J. Garrigues, M. Glanc, N. Laguarda-Miro, C. Olguin. Sens. Actuators A: Phys. (2011), 570-582. doi:10.1016/j.sna.2011.09.039.

[42] I. Campos, M. Alcañiz, D. Aguado, R. Barat, J.Ferrer, L.Gil, M. Marrakchi , R. Martínez-Mañez, J. Soto, J.L. Vivancos. Water Res 46 (2012) 2605-2614.

[43] L. Gil, J.M. Barat, D. Baigts, R. Martínez-Máñez, E. García-Breijo, M-C. Aristoy, F. Toldrá, J. Soto, E. Llobet, Food Chem 126 (2011) 1261-1268.

[44] I. Campos, R. Masot, M. Alcañiz, L. Gil, J.L. Vivancos, E. García-Breijo, R. H. Labrador, J. M. Barat, R. Martínez-Máñez, J. Soto. Sens. Actuators B 149 (2010) 7178. 